J. Clin. Chem. Clin. Biochem.

Vol. 18, 1980, pp. 771-773

\title{
Superoxide Dismutase, Catalase and Glutathione Peroxidase Activities in Maternal and Cord Blood Erythrocytes
}

\author{
By A. Agostoni, Gian Carla Gerli, L. Beretta, M. Bianchi \\ Clinica Medica VII, Ospedale "San Paolo", University of Milan, Milan, (Italy) \\ M. Vignali and F. Bombelli \\ Clinica Ostetrica e Ginecologica, Ospedale "L. Sacco", University of Milan, Milan, (Italy)
}

(Received March 17/June 26, 1980)

Summary: The "antioxidant" enzymes superoxide dismutase, catalase and glutathione peroxidase were assayed in a biological model with low oxygen tension (red cells from cord blood of newborn infants). Catalase and glutathione peroxidase activities in red cells of newborns were significantly lower when compared with their mothers and with normal controls. In contrast, superoxide dismutase activity was unchanged. Thus, normal activities of superoxide dismutase seem to be necessary in order to protect red blood cells from superoxide radicals during foetal life, while even low activities of catalase and glutathione peroxidase are sufficient to protect red blood cells from hydrogen peroxide. No correlation was found between the "antioxidant" enzyme activities present in cord blood erythrocytes and the bilirubin concentrations during the first days of life.

\section{Superoxiddismutase-, Katalase- und Glutathionperoxidase-Aktivitäten in mütterlichen und Nabelschnurblut-Erythrocyten}

Zusammenfassung: Die als „Antoxidans“ wirkenden Enzyme Superoxiddismutase, Katalase und Glutathionperoxidase wurden in einem biologischen Modell mit geringer Sauerstoffspannung - Erythrociten aus dem Nabelschnurblut Neugeborener - bestimmt. Die Aktivitäten von Katalase und Glutathionperoxidase in Erythrocyten Neugeborener sind, verglichen mit denen ihrer Mütter und normaler Kontrollen, signifikant geringer. Im Gegensatz dazu war die Aktivität der Superoxiddismutase unverändert. Normale Aktivitäten der Superoxiddismutase scheinen erforderlich zu sein, um Erythrocyten während des Foetallebens vor Superoxidradikalen zu schützen, während auch geringe Aktivitäten von Katalase und Glutathionperoxidase für den Schutz der Erythrocyten vor Wasserstoffperoxid ausreichend sind. Zwischen den als „Antoxidans“ wirkenden Enzymaktivitäten in Nabelschnurbluterythrocyten und den Bilirubinkonzentrationen während der ersten Lebenstage wurde keine Beziehung gefunden.

\section{Introduction}

Various biological injuries can be produced by free oxygen radicals (1-7).

Much evidence has accumulated that superoxide dismutase plays a key role in protecting aerobic systems against superoxide radicals (8). In fact the complete reduction of a molecule of oxygen yields. intermediates, including $\mathrm{O}_{2}^{-}$(superoxide radical), whose dismutation is catalysed by superoxide dismutase according to the reaction:

$$
\mathrm{O}_{2}^{-}+\mathrm{O}_{2}^{-}+2 \mathrm{H}^{+} \rightarrow \mathrm{H}_{2} \mathrm{O}_{2}+\mathrm{O}_{2}
$$

Moreover there are ancillary mechanisms, catalases and peroxidases, which can remove hydrogen peroxides $(6,9-12)$. These enzymes are ubiquitous in the cells of respiring organisms, where they counteract the potential toxicity of superoxide radical anions or hydrogen peroxide. These enzymatic systems cope well at normal oxygen partial pressure, but are insufficient at higher levels. Studies in bacteria and in mammalian cells have confirmed that superoxide dismutase can be induced by high oxygen pressure and diminished during hypoxia (13-17). A simple model for investigating the behaviour of "antioxidant" enzymes in human beings is represented by the comparative study of these enzymes in cord 
blood of newborn infants, where the oxygen pressure is very low, and in the blood of their mothers. In the present paper we report the activities of superoxide dismutase, catalase and glutathione peroxidase in red cells from cord blood of newborn infants and from the blood of their mothers, obtained at the same time. No comparative study of these three enzymes has been previously reported.

\section{Materials and Methods}

Samples were obtained from the cord blood of 21 full-term newborn infants, and from the venous blood of their mothers and 40 healthy adults. All newborns had a normal Apgar score and their mothers had no evidence of haematological or dismetabolic diseases. Blood samples from mothers were obtained at the beginning of labour.

All blood samples (collected in EDTA) were centrifuged at $2500 \mathrm{rpm}$ for 10 minutes. Plasma and buffy coat were removed by aspiration and red cells washed three times with cold $\left(4^{\circ} \mathrm{C}\right)$ saline.

Superoxide dismutase activity, determined in chloroform/ ethanol-treated haemolysates according to Fridovich and coworkers $(8,18)$, was calculated using a calibration curve of Sigma purified bovine superoxide dismutase. The values were expressed as $\mu \mathrm{g}$ of superoxide dismutase per $\mathrm{g}$ of haemoglobin $(\mu \mathrm{g} / \mathrm{g} \mathrm{Hb})$. Catalase activity was determined according to Beers \& Sizer's method (19), on haemolysate prepared as indicated by Beutler (20), and expressed as first order reaction rate constant per $\mathrm{g}$ of haemoglobin $(\mathrm{k} / \mathrm{g} \mathrm{Hb})$. Glutathione peroxidase was assayed on crude haemoly sate using $t$-butylhydroperoxide as a substrate (20); enzyme activity was expressed as $\mu$ moles of NADPH oxidized per minute per $\mathrm{g}$ of haemoglobin (U/g Hb).

Each assay was performed at $30^{\circ} \mathrm{C}$ and was carried out in duplicate for superoxide dismutase and glutathione peroxidase and in triplicate for catalase. Haemoglobin was determined in duplicate on each haemolysate according to the method recommended by the International Committee for Standardization in Haematology (21). Statistical analysis was performed by the Student's $t$ test, while differences between newborns and their mothers were tested by paired t statistics.

\section{Results}

The mean values and statistical differences of erythrocyte superoxide dismutase, catalase and glutathione peroxidase activities in cord blood and in venous blood from mothers and normal subjects are reported in table 1. No significant sex difference was found in newborns (data not reported in tab. 1) and in adults. The activities of erythrocyte catalase and glutathione peroxidase in cord blood of newborn infants were significantly lower $(P<0.001)$ than those of both mothers and normal controls.

Mothers' erythrocyte catalase and glutathione peroxidase were higher than in normal women $(\mathrm{P}<0.02$ and $\mathrm{P}<0.001$ respectively). The values of erythrocyte superoxide dismutase activity were similar in all the groups of subjects examined.

\section{Discussion}

In order to evaluate the influence of very low oxygen pressure on erythrocyte "antioxidant" enzymes we studied superoxide dismutase, catalase and glutathione peroxidase activities in cord blood of newborn infants and in the blood of their mothers. Mothers, in fact, appear to be the most suitable control group, because maternal influence on cord blood enzymes, is then taken into account.

Our results indicate that erythrocyte glutathione peroxidase and catalase activities were significantly lower in cord blood than in mothers, while superoxide dismutase was unchanged. Low activities of glutathione peroxidase in cord blood were previously reported by many authors (22-28). Michelson et al. (29) found no significant difference in erythrocyte catalase and superoxide dismutase in cord blood of a small number of newborn infants when compared with their mothers. Yoshioka et al. (30) also found no difference between maternal and cord blood erythrocyte superoxide dismutase. Only Legge et al. (31) reported significantly lower superoxide dismutase activity in red cells of cord blood of newborns when compared with adult controls: the data for adult red cells, however, were determined for a previous publication. It is worth mentioning that Bonta et al. (32) found higher red cell superoxide dismutase activity in the younger gestational age premature infants, and they suggest that "although $\mathrm{PaO}_{2}$ is constant throughout

Tab. 1. Erythrocyte superoxide dismutase, catalase and glutathione peroxidase activities in normal subjects and in paired samples of maternal and cord blood, means \pm standard deviations. Superoxide dismutase values are given in $\mu \mathrm{g}$ of enzyme per $\mathrm{g}$ of haemoglobin. Catalase activities are expressed as first order reaction rate constants per $\mathrm{g}$ of haemoglobin. Glutathione peroxidase activities are listed as International Units (U) per $\mathrm{g}$ of haemoglobin. NS = not significant.

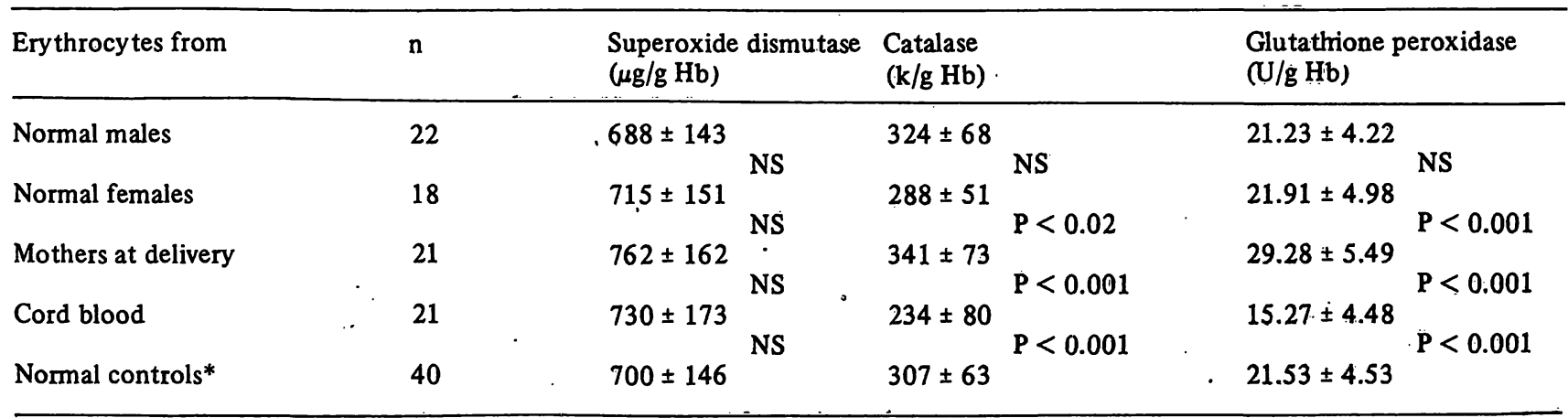

* The values are taken from the groups of 22 normal males and 18 normal females. 
gestation a higher basal superoxide dismutase level may be necessary to protect immature cell membranes during early gestation with decreasing dependence upon this mechanism as the fetus matures". In contrast, reduced values of superoxide dismutase have been observed in bacteria, macrophages, and lung and brain homogenates during hypoxia $(14,17)$. It may be that red cells of cord blood contain normal superoxide dismutase levels for

1) protection during foetal life (even low oxygen tension may produce superoxide radicals (32) and fetal haemoglobin is more susceptible to methaemoglobin formation than adult haemoglobin (33), thus increasing superoxide flux) and

2) toleration of the relative hyperoxia at birth.

In contrast, at low oxygen pressure as in cord blood, $\mathrm{H}_{2} \mathrm{O}_{2}$ may be produced at a low rate, and owing to its relative chemical stability can diffuse from cells without causing damage (34). Thus, low levels of catalase and glutathione peroxidase may be sufficient to protect red blood cells from this oxygen intermediate.
It is worth mentioning that no correlation was found between the levels of erythrocyte antioxidant enzymatic activities present in cord blood and the levels of bilirubin during the first days of life.

A good agreement on superoxide dismutase, catalase and glutathione peroxidase activities in pregnant women does not exist in previously published data $(27-29,35)$, probably because the blood samples were not obtained at the same period of pregnancy. In the group of mothers we have studied, the blood samples were obtained at the beginning of labour, and the three enzymes were tested on the same sample. While erythrocyte superoxide dismutase values were unchanged, our data indicate a significant increase of glutathione peroxidase and catalase in comparison with normal women. The high levels of glutathione peroxidase and catalase in pregnant women could be related to a hormonal effect and not to the increase in reticulocytes and younger cells (as suggested by $R u$ dolph \& Wong (27)), as the activities of these enzymes are not age-dependent $(36,37)$.

\section{References}

1. Matsumura, G., Herp, A. \& Pigman, W. (1966), Radiat. Res. $28,735-752$.

2. Lavelle, F., Michelson, A. M. \& Dimitrejevic, L. (1973), Biochem. Biophys. Res. Comm. 55, 350-357.

3. Kellog, E. W. \& Fridovich, I. (1975), J. Biol. Chem. 250, 8812-8817.

4. Goldberg, B. \& Stern, A. (1976), J. Biol. Chem. 251, 6468-6470.

5. Misra, H. P. \& Fridovich, I. (1976), Arch. Biochem. Biophys. $176,577-581$.

6. Cohen, G. \& Hochstein, P. (1963), Biochemistry 2, 14201428.

7. Ismail, G., Sawyer, W. D. \& Wegener, W. S. (1977), Proc. Soc. Exp. Biol. Med. 155, 264-269.

8. Mc Cord, G. M. \& Fridovich, I. (1969), J. Biol. Chem. 244, 6049-6055.

9. Jacob, H. S., Ingbar, S. H. \& Jandl, J. H. (1965), J. Clin. Invest. 44, 1187-1199.

10. Nicholls, P. (1972), Biochim. Biophys. Acta 279, 306-309.

11. Mills, G. C. (1957), J. Biol. Chem. 229, 189-197.

12. Mills, G. C. \& Randall, H. P. (1958), J. Biol. Chem. 232, 589-598.

13. Gregory, E. M. \& Fridovich, I. (1973), J. Bạcteriol. 114, $543-548$.

14. Gregory, E. M. \& Fridovich, I. (1973), J. Bacteriol. 114, 1193-1197.

15. Crapo, J. G. \& Tierney, D. F. (1974), Am. J. Physiol. 226, 1401-1407.

16. Stevens, J. B. \& Autor, A. P. (1977), Lab. Invest. 37, 470478.

17. Liu, J., Simonn, L. M., Phillips, J. R. \& Róbin, E. D. (1977), J. Appl. Physiol. 42, 107-110.

18. Misra, H. P. \& Fridovich, I. (1972), J. Biol. Chem. 247, $3170-3175$.

19. Beers, R. F. \& Sizer, I. W. (1952), J. Biol. Chem. 195, $133-140$.

20. Beutler; E. (1975), in Red cell metabolism. A manual of biochemical methods. Grune \& Stratton Inc., New York.

21. International Committee for Standardization in Haematology (1978), J. Clin. Pathol. 31, 139-143.

22. Gross, R. T., Bracci, R., Rudolph, N., Shroeder, E. \& Kochen, J. A. (1967), Blood 29, 481-493.

23. Glader, B. E. \& Conrad, M. E. (1972), Pediat. Res. 6, 900-904.

24. Konrad, P. N., Valentine, W. N. \& Paglia, D. E. (1972), Acta Haematol. 48, 193-201.

25. Emerson, P. M., Mason, D. Y. \& Cuthbert, J. E. (1972), Brit. J. Haematol. 22, 667-680.

26. Lie-Injo, L. E., Wong, P. W. \& Ng, T. (1973), Brit. J. Haematol. $25,577-584$.

27. Rudolph, N. \& Wong, S. L. (1978), Pediat. Res. 12, 789792.

28. Perona, G., Guidi, G. C., Piga, A., Cellerino, R., Milani, G., Colautti, P., Moschini, G. \& Stievano, B. M. (1979), Brit. J. Haematol. 42, 567-574.

29. Michelson, A. M., Puget, K., Durosay, P. \& Bonneau, J. D. (1977), in Superoxide and Superoxide Dismutase (Michelson, A. M., Mc Cord, J. M. \& Fridovich, I. eds.) p. 467-499, Academic Press, London.

30. Yoshioka, T., Sugiue, A., Shimada, T. \& Utsumi, K. (1979), Biol. Neonate 36, 173-180.

31. Legge, M., Brian, M., Winterbourn, C. \& Carrel, R. (1977), Aust. Paediat. J. 13, 25-28.

32. Bonta, B. W., Gawron, E. R. \& Warshaw, J. B. (1977), Pediat. R̂̉. 11, 754-757.

33. Wind, M. \& Stern, A. (1977), Experientia 33, 1500-1501.

34. Mc Cord, J. M., Keele, B. B. Jr. \& Fridovich, I. (1971), Proc. Nat. Acad. Sci. 68, 1024-1027.

35. Behne, D. \& Wolters, W. (1979), J. Clin. Chem. Clin. Biochem. 17, 133-135.

36. Cellerino, R., Guidi, G. \& Perona, G. (1976), Scand. J. Haematol. 17, 111-116.

37. Balcerzak, S. P., Vester, J. W. \& Doyle, A. P. (1966), J. Lab. Clin. Med. 67, 742-756.

Prof. A. Agostoni Clinica Medica VII Ospedale "San Paolo" Via di Rudini, 8 I-20142 Milano 
